\section{Evaluating Beautyberry and Fig Species as Potential Hosts of Invasive Crapemyrtle Bark Scale in the United States}

\author{
Bin $\mathrm{Wu}^{1}$, Runshi Xie ${ }^{1}$, Gary W. Knox ${ }^{2}$, Hongmin $\mathrm{Qin}^{3}$, and \\ Mengmeng $\mathrm{Gu}^{4}$
}

AdDitionAl INDEX wORDs. exotic insect, green industry, host range, host suitability

\begin{abstract}
Summary. Crapemyrtle bark scale [CMBS (Acanthococcus lagerstroemiae)], a newly emerged pest in the United States, has spread to 16 U.S. states and unexpectedly spread on a native species american beautyberry (Callicarpa americana) in Texas and Louisiana in 2016 since it was initially reported on crapemyrtles (Lagerstroemia sp.) in Texas in 2004. The infestation of CMBS negatively impacted the flowering of crapemyrtles. We observed the infestation on the two most commercially available edible fig (Ficus carica) cultivars Beer's Black and Chicago Hardy in a preliminary trial in 2018. To help estimate CMBS potential in aggravating risks to the ecosystem stability and the green industry, we conducted a host range and suitability test using 'Bok Tower' american beautyberry as a positive control with other eight beautyberry (Callicarpa) species [mexican beautyberry (C. acuminata), 'Profusion' bodinieri beautyberry (C. bodinievi), 'Issai' purple beautyberry ( $C$. dichotoma), japanese beautyberry ( $C$. japonica var. luxurians), 'Alba' white-fruited asian beautyberry (C. longissima), taiwan beautyberry (C. pilosissima), luanta beautyberry (C. randaiensis), and willow-leaf beautyberry (C. salicifolia)] and three fig (Ficus) species [creeping fig (F. pumila), roxburgh fig (F. auriculata), and waipahu fig (F. tikoua)] over 25 weeks. All the tested beautyberry species and waipahu fig sustainably supported the development and reproduction of nymphal CMBS and were confirmed as CMBS hosts. Furthermore, comparing with the control, mexican beautyberry, 'Profusion' bodinieri beautyberry, taiwan beautyberry, and willow-leaf beautyberry were significantly less suitable, while 'Issai' purple beautyberry, japanese beautyberry, 'Alba' white-fruited asian beautyberry, and luanta beautyberry were as suitable as 'Bok Tower' american beautyberry. Thus, when using beautyberries in landscapes, their different potential to host CMBS should be considered to minimize spreading CMBS through the native ecosystems.
\end{abstract}

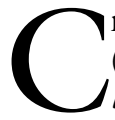
rapemyrtle bark scale [CMBS (Acanthococcus lagerstroemi$a e)]$ is a sap-sucking hemipteran native to some Asian countries (Kozár et al., 2013). Since initially detected and identified in Texas in 2004 (Merchant et al., 2014), the CMBS has spread in the United States to 16 states [Alabama, Arkansas, Delaware, Georgia, Kansas, Louisiana, Maryland, Mississippi, New Mexico, North Carolina, Oklahoma, South Carolina, Tennessee, Texas, Virginia (EDDMapS, 2021; Gill, 2021), and Washington (C.S. Arnold, personal communication)]. Black sooty mold fungi growth resulting from CMBS honeydew secretion (Reynolds, 1999) interfered with the photosynthesis of crapemyrtles [Lagerstroemia sp. (Insausti et al., 2015; Vafaie et al., 2020)]. It negatively affected the aesthetic quality of ornamental plants $(\mathrm{Gu}$ et al., 2014; Zhang and Shi, 1986), and reduced the flowering and yield of pomegranate [Punica granatum (Jiang and Xu, 1998; Ma, 2011)].

Infestation by CMBS was reported on plant species that include commercially important crops in Asia. However, only a few published records regarding CMBS are associated with plants other than crapemyrtles, loosestrifes (Lythrum sp.), pomegranate, and caneberries (Rubus sp.) in the United States (Wu et al., 202l; Xie et al., 2020). The more plants beyond the loosestrife family (Lythraceae) and rose family (Rosaceae) to test, the more insights into the relationship between host suitability levels and host classification to obtain, which help uncover the main determinants of CMBS-host associations and better control CMBS. Even though 'Tiger' edible fig (Ficus carica) did not support nymphal CMBS's development and reproduction (Wang et al., 2019), we observed male pupae and gravid females of CMBS on 'Beer's Black' and 'Chicago Hardy' edible fig in a preliminary trial in 2018 (Fig. 1). The infestation of CMBS observed on edible fig led to concerns about its threat potential to the edible fig industry. A significant reduction in yield and quality caused by the heavy infestation of CMBS has been reported on another fruit crop, pomegranate (Jiang and $\mathrm{Xu}, 1998$; $\mathrm{Ma}, 2011)$. Further host range tests using other fig (Ficus) species other than edible fig would provide beneficial information to the green industry in the United States.

Additionally, it was Texarkana, TX and Bossier City, LA where the CMBS infestations were first reported on a U.S native plant, american beautyberry [ Callicarpa americana $(\mathrm{Gu}, 2018)]$. Subsequently, the infestations on american beautyberry were confirmed in other places, including College Station, TX and Hammond, LA. Almost overlapping crapemyrtles' distribution in the United States, american beautyberry is distributed from Maryland and Virginia south to Florida and west to Arkansas, OK, and Texas (Contreras et al., 2014). Suppose CMBS spread through the native population of american beautyberry. In that case, it may exacerbate CMBS infestations to other plant species in the United States and even reduce the diversity of native species by indirectly disrupting the local food chain of the wildlife when used in landscapes (Resasco et al., 2014). There are many other beautyberry (Callicarpa) and fig species being introduced from other countries (Berg, 1989; Chang et al., 1998d; Pei et al.,

\begin{tabular}{llll}
\hline $\begin{array}{l}\text { Units } \\
\text { To convert U.S. to SI, } \\
\text { multiply by }\end{array}$ & U.S. unit & SI unit & $\begin{array}{l}\text { To convert SI to U.S., } \\
\text { multiply by }\end{array}$ \\
\hline 0.3048 & $\mathrm{ft}$ & $\mathrm{m}$ & 3.2808 \\
3.7854 & $\mathrm{gal}$ & $\mathrm{L}$ & 0.2642 \\
2.54 & inch $(\mathrm{es})$ & $\mathrm{cm}$ & 0.3937 \\
25.4 & inch $(\mathrm{es})$ & $\mathrm{mm}$ & 0.0394 \\
$\left({ }^{\circ} \mathrm{F}-32\right) \div 1.8$ & ${ }^{\circ} \mathrm{F}$ & ${ }^{\circ} \mathrm{C}$ & $\left({ }^{\circ} \mathrm{C} \times 1.8\right)+32$
\end{tabular}



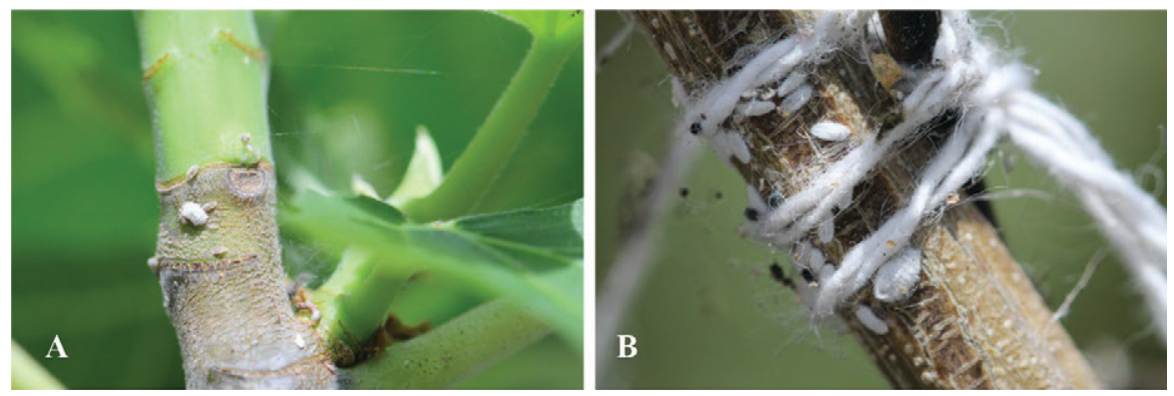

Fig. 1. Infestation of crapemyrtle bark scale observed on (A) 'Beer's Black' and (B) 'Chicago Hardy' edible fig.

1982), which are important in ecosystems (Martin and Mott, 1997), landscapes (Dirr, 1990; Greer and Dole, 2009; Wong, 2007), and pharmaceutical industries (Chen et al., 2009; Gaire et al., 2011; Liao et al., 2012; Wu et al., 2015). Therefore, this study was aimed to investigate the potential hosts of CMBS by using other beautyberry and fig species to extend the host range investigation, which helps estimate its potential risks to the economy and ecology while

Received for publication 26 May 2021. Accepted for publication 6 Oct. 2021

Published online 14 December 2021.

${ }^{1}$ Department of Horticultural Sciences, Texas A\&M University, College Station, TX 77843

${ }^{2}$ Department of Environmental Horticulture, University of Florida/IFAS North Florida Research and Education Center, Quincy, FL 32351

${ }^{3}$ Department of Biology, Texas A\&M University, College Station, TX 77843

${ }^{4}$ Department of Horticultural Sciences, Texas A\&M AgriLife Extension Service, College Station, TX 77843

We would like to acknowledge technical support from Jingru Lai and Qiansheng Li at Department of Horticultural Sciences, Texas A\&M AgriLife Extension Service, and Zinan Wang at Department of Entomology, Michigan State University. We also would like to thank the Agriculture Women Excited to Share Opinions, Mentoring and Experiences (AWESOME) faculty group of the College of Agriculture and Life Sciences at Texas A\&M University for assistance with editing the manuscript.

This work is partially supported by Crop Protection and Pest Management project "Integrated pest management strategies for crape myrtle bark scale, a new exotic pest" (grant no. 2014-70006-22632) project accession no. 10004888) and Specialty Crop Research Initiative project "Systematic Strategies to Manage Crapemyrtle Bark Scale, An Emerging Exotic Pest" (grant no. 2017-51181-26831/project accession no. 1013059) from the U.S. Department of Agriculture (USDA), National Institute of Food and Agriculture. Any opinions, findings, conclusions, or recommendations expressed in this publication are those of the author(s) and do not necessarily reflect the view of the USDA.

M.G. is the corresponding author. E-mail: mgu@ tamu.edu.

This is an open access article distributed under the CC BY-NC-ND license (https://creativecommons. org/licenses/by-nc-nd/4.0/)

https://doi.org/10.21273/HORTTECH04897-21 developing a strategic management by using less suitable plant screened from the tested plants for CMBS.

When an insect can complete its life cycle on a plant species, including feeding and oviposition by an adult female, this plant species is considered as the insect's host, and a list of the plant species used as hosts is called host range (Bernays and Chapman, 1994; Schaffner, 2001). In this study, the potential hosts were confirmed by recording the infestation of CMBS with gravid female's newly emerged on tested plants. Compared with the confirmed host american beautyberry as the control plant, the host suitability was evaluated by counting and comparing the number of newly developed CMBS male pupae and gravid females by plant species over 25 weeks.

\section{Materials and methods}

Test Plants AND Insect SOURCE. 'Bok Tower' american beautyberry, mexican beautyberry (C. acuminata), 'Profusion' bodinieri beautyberry $(C$. bodinieri), 'Issai' purple beautyberry (C. dichotoma), japanese beautyberry (C. japonica var. luxurians), 'Alba' white-fruited asian beautyberry (C. $10^{-}$ ngissima), taiwan beautyberry (C. pilosissima), luanta beautyberry ( $C$. randaiensis), and willow-leaf beautyberry (C. salicifolia), creeping fig $(F$. pumila), roxburgh fig ( $F$. auriculata), and waipahu fig (F. tikoua) were tested in this study (Table 1 ). All tested plants (plant height roughly ranged from 0.28 to $0.79 \mathrm{~m}$ for beautyberries and 0.24 to $0.72 \mathrm{~m}$ for figs) were provided from John Fairey Garden Conservation Foundation (Hempstead, TX). They were individually transplanted into l-gal pots containing potting substrate (Jolly Gardener Pro-Line C/25; Oldcastle Lawn \& Garden, Poland
Spring, ME). All plants were maintained in handmade chiffon meshcovered (Fabric Wholesale Direct, Farmingdale, NY) cages $(75 \mathrm{~cm}$ length, $50 \mathrm{~cm}$ width, $40 \mathrm{~cm}$ height) at $25 \pm 5{ }^{\circ} \mathrm{C}, 50 \% \pm 10 \%$ relative humidity $(\mathrm{RH})$, and a photoperiod of 10.5/13.5 h (light/dark) for acclimation before CMBS inoculation. The CMBS-infested branches were collected in crapemyrtle plants from a nursery at the Department of Horticultural Sciences, Texas A\&M University, College Station (lat. $30^{\circ} 36^{\prime} 31.9^{\prime \prime} \mathrm{N}$, long. $\left.96^{\circ} 21^{\prime} 1.9^{\prime \prime} \mathrm{W}\right)$.

HOST RANGE AND SUITABILITY TEST. The experiment was conducted in the greenhouse at the Department of Horticultural Sciences, Texas A\&M University. Three replicates, placed on different benches in the same greenhouse, were tested simultaneously at $25 \pm 5^{\circ} \mathrm{C}, 50 \% \pm 10 \% \mathrm{RH}$, and a photoperiod of 10.5/13.5 h (light/dark). Each replicate consisted of one plant per species (Table l) with the CMBSinfested crapemyrtle branches (Fig. 2A) inoculated on 9 May 2019. Before being randomly attached to branches of each plant by laboratory sealing film (parafilm M; Amcor, Neenah, WI), all except five ovisacs on the branches were removed (Fig. 2B). To ensure successful CMBS inoculation, each test plant was tied again with a new infected branch containing five ovisacs on 15 June 2019. The CMBS males were identified by the snow-white tubular sac $(\approx 1.0 \mathrm{~mm}$ long, $\approx 0.5 \mathrm{~mm}$ wide), and the females were identified by the white round oval-shaped ovisac ( $\approx 2.0 \mathrm{~mm}$ long, $\approx 1.2 \mathrm{~mm}$ wide $)$ (Wang et al., 2016) (Fig. 2C). The numbers of males and females on each plant, respectively, were counted biweekly from 3 weeks after the first inoculation (WAI).

Statistical anALYSES. The numbers of CMBS males and females were, respectively, transformed as $\log _{10}$ $[($ no. CMBS $)+1]$ to improve data distribution normality before data analysis. Then, the log-transformed data were analyzed as repeated measures analysis of variance (ANOVA) with a mixed effect using statistical software (JMP version 16; SAS Institute, Cary, NC). Data collection time and plant species were assigned with full factorial. Three subjects for each species as the blocks were included as a random effect. The least-squares means 
Table 1. Twelve plant species as host candidates of crapemyrtle bark scale were used in the host range confirmation test.

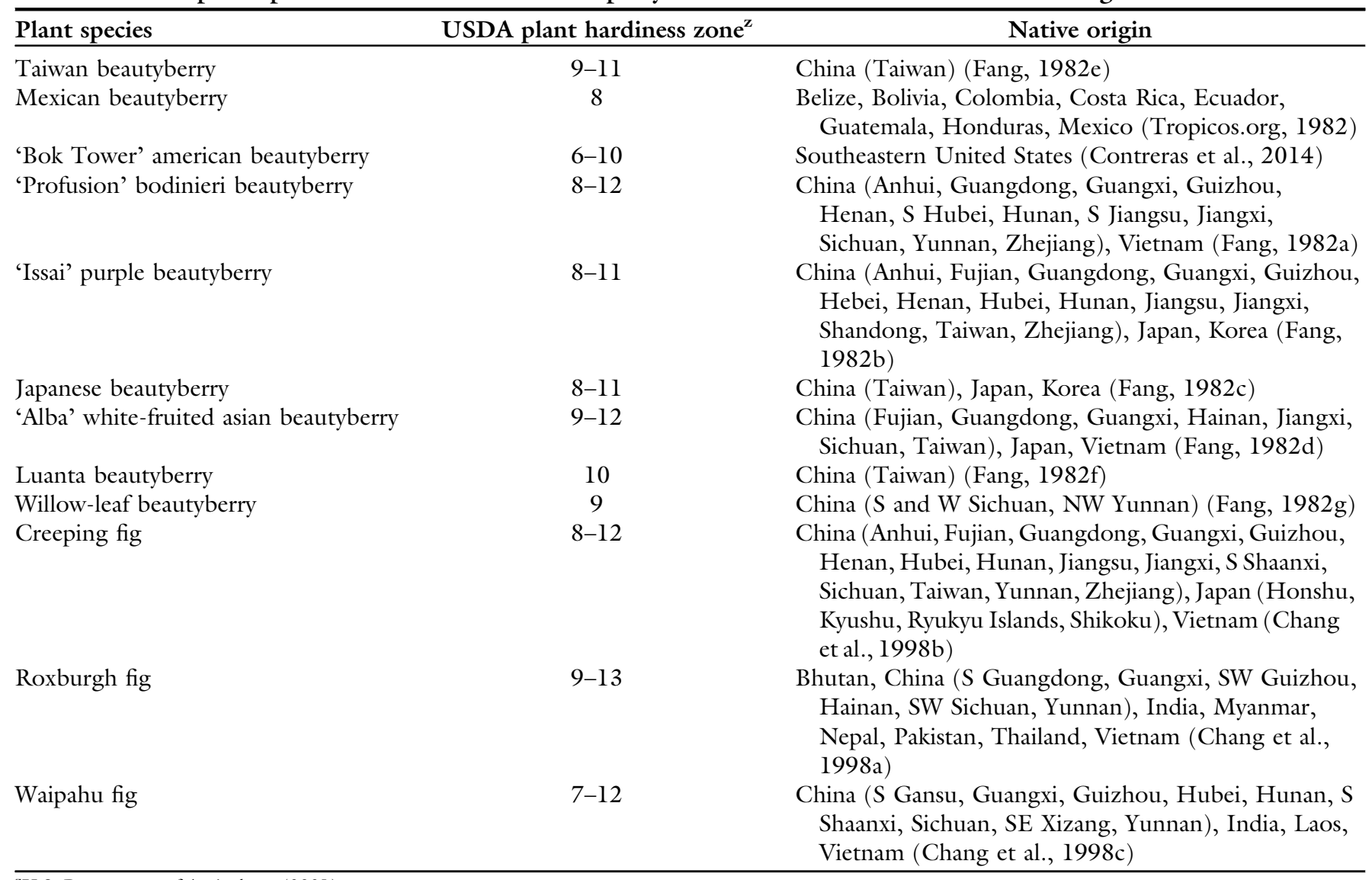

${ }^{\mathrm{z} U . S . ~ D e p a r t m e n t ~ o f ~ A g r i c u l t u r e ~(2021) . ~}$

(LSMeans) of the numbers of CMBS males and females were separated using Tukey's honestly significant difference (HSD) test $(\alpha=0.05)$ to see if the numbers of CMBS males and females differed significantly by species over the 25 weeks. The LSMeans of the CMBS males and females on the nine beautyberry species were compared using Tukey's HSD test $(\alpha=0.05)$ to categorize the tested plants into different suitability groups better. Inversetransformed data were presented when needed. The data were plotted using graphing software (Graphpad Prism version 9; Graphstats Technologies, San Diego, CA).

\section{Results and discussion}

The number of newly developed CMBS males and ovipositing gravid females on all tested beautyberry species and waipahu fig increased from 3 WAI and 5 WAI to $25 \mathrm{WAI}$, respectively, which indicated that these plant species could sustain the completion of the CMBS life cycle (Figs. 3 and 4D). Less than three CMBS males and no females were seen on either roxburgh fig or creeping fig during the 25 -week host confirmation experiment. Thus, in addition to the positive control 'Bok Tower' american beautyberry, our study first added eight more beautyberries ('Issai' purple beautyberry, luanta beautyberry, 'Alba' white-fruited asian beautyberry, japanese beautyberry, willow-leaf beautyberry, mexican beautyberry, taiwan beautyberry, 'Profusion' bodinieri beautyberry) in the sage family (Lamiaceae) and waipahu fig in the fig family (Moraceae) (U.S. Department of Agriculture, Agricultural Research Service, 2021) into the known host range of CMBS in the United States (Wu et al., 2021; Xie et al., 2020). The CMBS should be defined as a polyphagous pest since it was able to feed and reproduce on multiple plant species from different families (Bernays and Chapman, 1994; Schoonhoven et al., 2005; Ward and Spalding, 1993).

Due to global warming, increasing human population densities, and escalating international trade of ornamental plants, exotic insect invasions have occurred at an increasing rate (Bradshaw et al., 2016; Early et al., 2016). American beautyberry has medium food value for wildlife (Martin and Mott, 1997), and in a study over five winters in Virginia, american goldfinch (Spinus tristis), dark-eyed junco (Junco byemalis), and house finch (Haemorhous mexicanus) feed heavily on crapemyrtle seeds, in additional five species occasionally feeding on crapemyrtles (Graves, 2018). Importantly, there is significant overlap between crapemyrtle (the CMBS primary host) and american beautyberry (the native plant) geographical distribution, which could provide a continuum for CMBS dispersal by wildlife (Martin and Mott, 1997; McClure, 1990). The interaction between CMBS, plants, and the wildlife might be a possible and reasonable explanation as to why CMBS is spreading so rapidly across the United States (EDDMapS, 2021; Gu, 2018; Mazzi and Dorn, 2012). It is reasonable to believe that any 

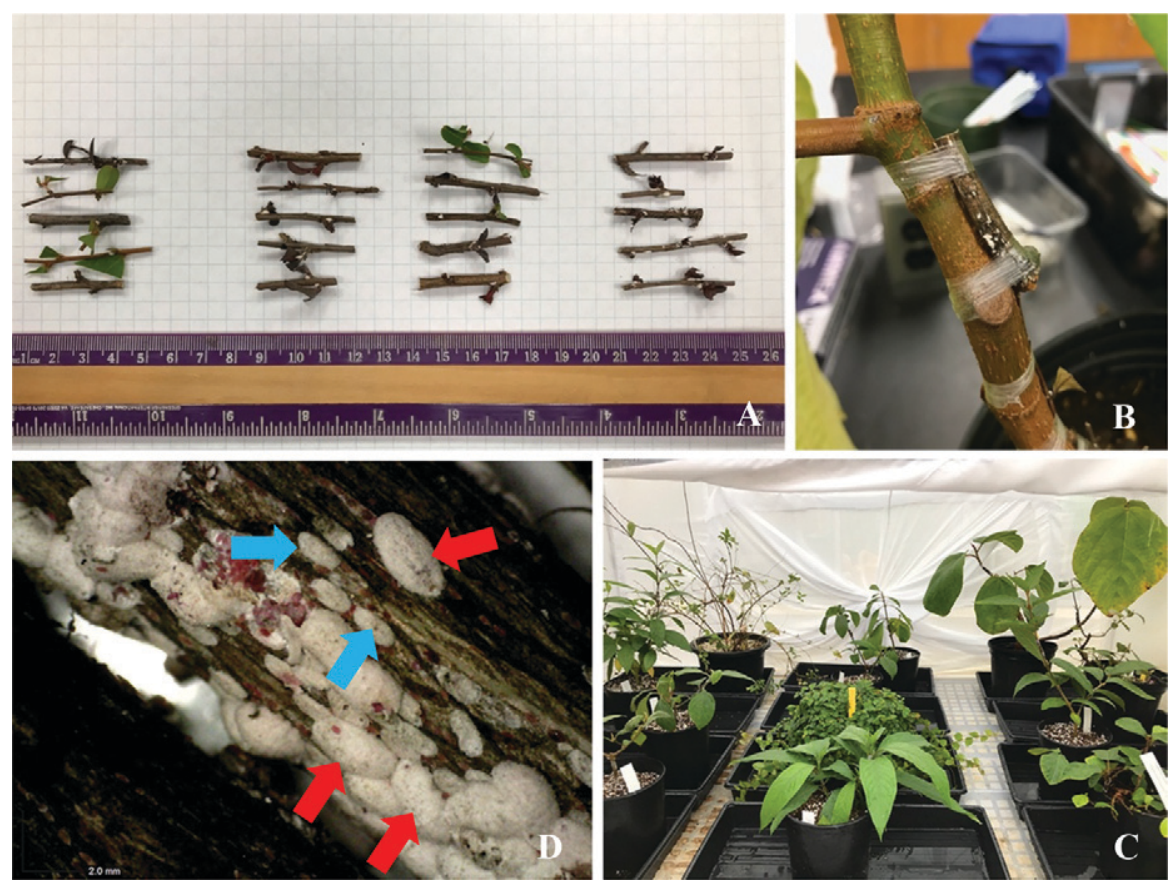

Fig. 2. Inoculation of crapemyrtle bark scale (CMBS) on nine beautyberry and three fig species in one cage. (A) Three-centimeter-long (1.2 inch) CMBS-infected branches were collected from the nursery pad at Department of Horticultural Sciences, Texas A\&M University, College Station. (B) A CMBS-infected branch tied on roxburgh fig. (C) Males (indicated by blue arrows) were covered by white tubular sac, and the females (indicated by red arrows) were covered by white round oval-shaped ovisac. (D) A set of the 12 plant species inoculated with CMBS were placed in one cage. The cage was replicated three times, placed on different benches in the same greenhouse. horticultural plants that can be involved in the CMBS-plant-wildlife interaction will aggravate CMBS spread across the United States. Thereby, these confirmed host species, including american beautyberry, in both landscapes and the native habitat, are potentially exposed to the CMBS infestation, highlighting the importance of managing CMBS to protect the nursery industry, landscapes, and the ecosystems.

Only waipahu fig was determined as a host among the three tested fig species in this study, and the host suitability was evaluated among the beautyberry species. The number of newly developed CMBS males differed significantly with plant species $[F=$ $10.66 ; \mathrm{df}=8,18$ (numerator,

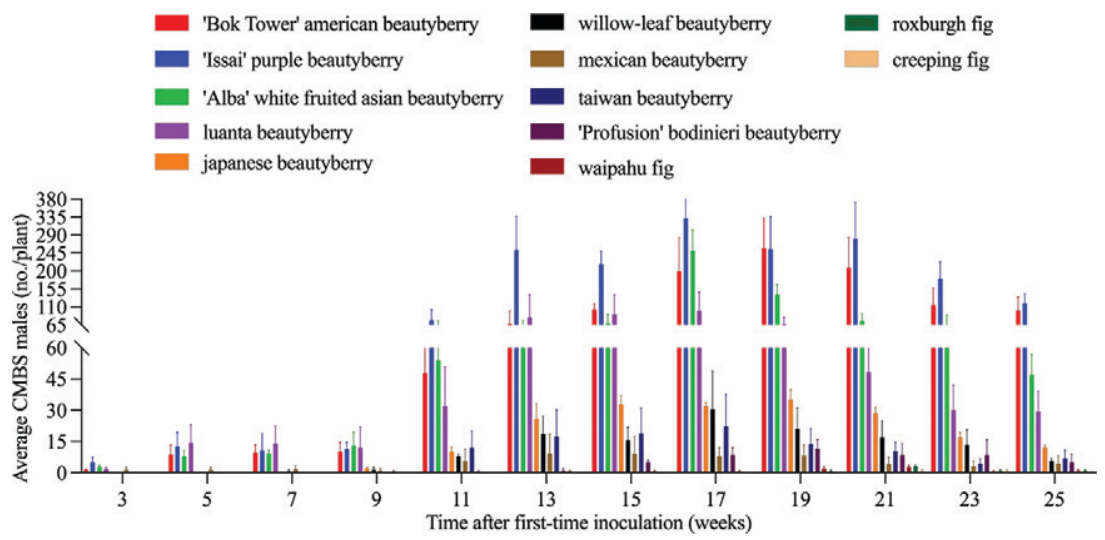

Fig. 3. Average number of male crapemyrtle bark scale (CMBS) developed on each beautyberry and fig species from 3 weeks after inoculation (WAI) to 25 WAI. Each bar represents the mean number of the males $( \pm S E)$ counted on each species. denominator); $P<0.0001]$ over 25 weeks $(F=136.46$; df $=11,198$; $P<0.0001)$. The number of the newly developed ovipositing gravid females were also significantly different with plant species ( $F=15.48$; $\mathrm{df}=8,18 ; P<0.0001)$ by data collection time $(F=176.17 ; \mathrm{df}=11$, 198; $P<0.0001$ ). In detail (Table 2 ), the inverse-transformed LSMeans of the number of CMBS with the inverse-transformed $95 \%$ confidence intervals $(\mathrm{CI})$ values on 'Issai' purple beautyberry [66 (29-151) males, 34 (18-62) females] was significantly higher than japanese beautyberry [8 (3-19) males, 5 (2-9) females], followed by willow-leaf beautyberry $[5$ (2-13) males, 3 (1-6) females ], taiwan beautyberry [3 (1-9) males, 2 (1-5) females], mexican beautyberry [2 (0-5) males and 1 (0-3) females], and 'Profusion' bodinieri beautyberry [1 (0-4) male and 1 (0-2) female]. Thus, the comparison results using the LSMeans indicated that the host suitability for CMBS differed significantly among the beautyberry species.

The nine tested beautyberry species were categorized into two groups based on their different suitability levels by comparing the inverse-transformed LSMeans of CMBS developed on the plants (Table 2), namely, the suitable group ('Bok Tower' american beautyberry, 'Issai' purple beautyberry, japanese beautyberry, 'Alba' white-fruited asian beautyberry, and luanta beautyberry) and the significantly less suitable group (mexican beautyberry, 'Profusion' bodinieri beautyberry, taiwan beautyberry, and willow-leaf beautyberry). The results on the CMBS host suitability in this experiment could be used when considering using different beautyberry species or cultivars in landscapes and future new cultivar development to minimize CMBS spread through the U.S. ecosystems.

Even though no sign of CMBS infestation was found on creeping fig or roxburgh fig, three males and two females were observed on waipahu fig. Further investigations among fig species or other crop plants would be necessary to evaluate the potential threat of CMBS to crops.

\section{Conclusion}

Besides the native beautyberry, 'Bok Tower' american beautyberry, we 


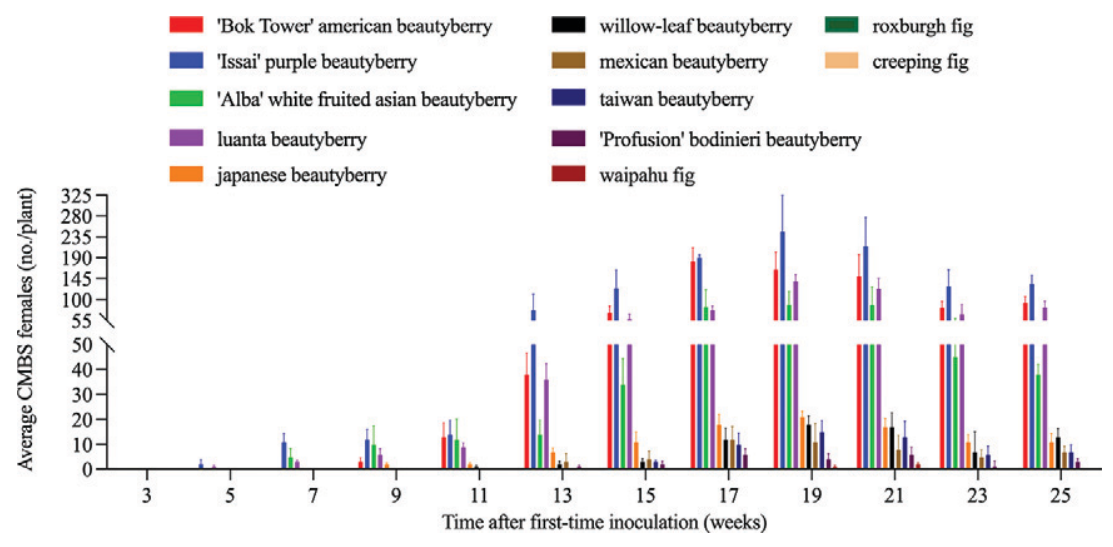

Fig. 4. Average number of female crapemyrtle bark scale (CMBS) developed on each beautyberry and fig species from 3 weeks after the inoculation (WAI) to 25 WAI. Each bar represents the mean number of the females $( \pm \mathrm{SE})$ counted on each species.

Table 2. Number of crapemyrtle bark scale (CMBS) developed on different beautyberry species over 25 weeks.

\begin{tabular}{lcc}
\hline Species & $\begin{array}{c}\text { Males } \\
{[\text { no. }(\mathbf{9 5 \%} \mathbf{C I})]^{\mathrm{z}}}\end{array}$ & $\begin{array}{c}\text { Females } \\
{[\text { no. (95\% CI)] }}\end{array}$ \\
\hline 'Bok Tower' american beautyberry & $41(18-95) \mathrm{ab}^{\mathrm{y}}$ & $18(9-33) \mathrm{ab}$ \\
'Issai' purple beautyberry & $66(29-151) \mathrm{a}$ & $34(18-62) \mathrm{a}$ \\
'Alba' white-fruited asian beautyberry & $37(16-85) \mathrm{abc}$ & $20(11-37) \mathrm{ab}$ \\
Luanta beautyberry & $21(9-48) \mathrm{abcd}$ & $13(7-25) \mathrm{abc}$ \\
Japanese beautyberry & $8(3-19) \mathrm{bcde}$ & $5(2-9) \mathrm{bcd}$ \\
Willow-leaf beautyberry & $5(2-13) \mathrm{cde}$ & $3(1-6) \mathrm{cd}$ \\
Taiwan beautyberry & $3(1-9) \mathrm{de}$ & $2(1-5) \mathrm{d}$ \\
Mexican beautyberry & $2(0-5) \mathrm{e}$ & $1(0-3) \mathrm{d}$ \\
'Profusion' bodinieri beautyberry & $1(0-4) \mathrm{e}$ & $1(0-2) \mathrm{d}$ \\
\hline
\end{tabular}

${ }^{\mathrm{z}} \mathrm{CI}=$ confidence interval. $\log$ transformation as $\log _{10}[($ no. CMBS $)+1]$ was conducted before data analysis. The inverse-transformed least-squares means (LSMeans) of CMBS males and females were presented with the inverse-transformed $95 \%$ CI.

${ }^{y}$ The numbers within a single column denoted by the same letters are not significantly different within 25 weeks, as compared by Tukey's honestly significant difference $(\alpha=0.05)$.

confirmed that eight more beautyberry species and waipahu fig were the CMBS hosts. This information should be taken into consideration when applying these confirmed hosts in nursery industries and landscape. The relatively wide host range and wide distribution of beautyberries could potentially exacerbate CMBS invasion across the United States, underlining the significance of CMBS management.

We categorized the beautyberry species into two groups based on their different suitability levels for CMBS. The suitable group ('Bok Tower' american beautyberry, 'Issai' purple beautyberry, japanese beautyberry, 'Alba' white-fruited asian beautyberry, and luanta beautyberry) and the significantly less suitable group (mexican beautyberry, 'Profusion' bodinieri beautyberry, taiwan beautyberry, and willow-leaf beautyberry). Thus, to minimize the infestation of CMBS throughout the United States, our results recommend beautyberries in the significantly less suitable group for landscape use.

\section{Literature cited}

Berg, C. 1989. Classification and distribution of Ficus. Experientia 45:605-611, https://doi.org/10.1007/BF01975677.

Bernays, E.A. and R.F. Chapman. 1994. Behavior: The process of host-plant selection, p. 95-165. In: T.A. Miller and H.S. van Emden (eds.). Host-plant selection by phytophagous insects. Vol. 2. Chapman \& Hall, New York, NY.

Bradshaw, C.J., B. Leroy, C. Bellard, D. Roiz, C. Albert, A. Fournier, M. BarbetMassin, J. Salles, F. Simard, and F. Courchamp. 2016. Massive yet grossly underestimated global costs of invasive insects. Nat. Commun. 7:1-8, https:// doi.org/10.1038/ncomms12986.
Chang, S., C. Wu, and Z. Cao. 1998a. Ficus auriculata, p. 170. In: S. Chang and C. Wu (eds.). Flora of China. Vol. 23. Science Press, Beijing, China.

Chang, S., C. Wu, and Z. Cao. 1998b. Ficus pumila, p. 205-206. In: S. Chang and C. Wu (eds.). Flora of China. Vol. 23. Science Press, Beijing, China.

Chang, S., C. Wu, and Z. Cao. 1998c. Ficus tikoua, p. 156-157. In: S. Chang and C. Wu (eds.). Flora of China. Vol. 23. Science Press, Beijing, China.

Chang, S., C. Wu, and Z. Cao. 1998d. Moraceae. Science Press, Beijing, China.

Chen, J., H. Wu, C. Peng, I. Chen, and S. Chu. 2009. seco-Abietane diterpenoids, a phenylethanoid derivative, and antitubercular constituents from Callicarpa pilosissima. J. Nat. Prod. 72:223-228, https://doi.org/ 10.1021/np80072lf.

Contreras, R.N., J.M. Ruter, and D.A. Knauft. 2014. Flower, fruit, and petiole color of american beautyberry (Callicarpa americana L.) are controlled by a single gene with three alleles. HortScience 49:422-424, https://doi.org/10.21273/ HORTSCI.49.4.422.

Dirr, M.A. 1990. Manual of woody landscape plants: Their identification, ornamental characteristics, culture, propagation and uses. 4th ed. Stipes, Champaign, IL.

Early, R., B.A. Bradley, J.S. Dukes, J.J. Lawler, J.D. Olden, D.M. Blumenthal, P. Gonzalez, E.D. Grosholz, I. Ibañez, and L.P. Miller. 2016. Global threats from invasive alien species in the twenty-first century and national response capacities. Nat. Commun. 7:1-9, https://doi.org/ $10.1038 /$ ncomms 12485 .

EDDMapS. 2021. Early detection \& distribution mapping system. 15 Mar. 2021. <https://www.eddmaps.org/distribution/ viewmap.cfm?sub=80722 $>$.

Fang, W. 1982a. Callicarpa bodinieri, p. 58-59. In: C. Pei and S. Chen (eds.). Flora of China. Vol. 65. Science Press, Beijing, China.

Fang, W. 1982b. Callicarpa dichotoma, p. 54-56. In: C. Pei and S. Chen (eds.). Flora of China. Vol. 65. Science Press, Beijing, China.

Fang, W. 1982c. Callicarpa japonica var. luxurians, p. 73. In: C. Pei and S. Chen (eds.). Flora of China. Vol. 65. Science Press, Beijing, China.

Fang, W. 1982d. Callicarpa longissima, p. 52-54. In: C. Pei and S. Chen (eds.). Flora of China. Vol. 65. Science Press, Beijing, China.

Fang, W. 1982e. Callicarpa pilosissima, p. 57-58. In: C. Pei and S. Chen (eds.). 
Flora of China. Vol. 65. Science Press, Beijing, China.

Fang, W. 1982f. Callicarpa randaiensis, p. 69. In: C. Pei and S. Chen (eds.). Flora of China. Vol. 65. Science Press, Beijing, China.

Fang, W. 1982g. Callicarpa salicifolia, p. 59-60. In: C. Pei and S. Chen (eds.). Flora of China. Vol. 65. Science Press, Beijing, China.

Gaire, B.P., R. Lamichhane, C.B. Sunar, A. Shilpakar, S. Neupane, and S. Panta. 2011. Phytochemical screening and analysis of antibacterial and antioxidant activity of Ficus auriculata (Lour.) stem bark. Pharmacogn. J. 3:49-55, https://doi.org/10.5530/ pj.2011.21.8.

Gill, S. 2021. Crapemyrtle bark scale: Now in Maryland. 10 Mar. 2021. <https:// extension.umd.edu/resource/crapemyrtlebark-scale $>$.

Graves, G.R. 2018. Avian feeding on seed of the exotic ornamental Lagerstroemia indica (crapemyrtle). Southeast. Nat. 17:293-297, https://doi.org/10.1656/ 058.017.0212.

Greer, L. and J.M. Dole. 2009. Woody cut stems for growers and florists: How to produce and use branches for flowers, fruit, and foliage. Timber Press, Portland, OR.

$\mathrm{Gu}, \mathrm{M} .2018$. Alternative hosts of crapemyrtle barkscale. Texas A\&M AgriLife Ext. Publ. EHT103. 11 May 2019. < https:// cdn-ext.agnet.tamu.edu/wp-content/ uploads /2018/10/EHT-103-alternativehosts-of-crapemyrtle-bark-scale.pdf $>$.

Gu, M., M. Merchant, J. Robbins, and J. Hopkins. 2014. Crape myrtle bark scale: A new exotic pest. Texas A\&M Agrilife Ext. Publ. EHT049. 11 May 2019. $<$ https://cdn-ext.agnet.tamu.edu/ wp-content/uploads/2018/10/ EHT-049-crape-myrtle-bark-scale-anew-exotic-pest.pdf $>$.

Insausti, P., E.L. Ploschuk, M.M. Izaguirre, and M. Podworny. 2015. The effect of sunlight interception by sooty mold on chlorophyll content and photosynthesis in orange leaves (Citrus sinensis L.). Eur. J. Plant Pathol. 143:559-565, https://doi.org/ 10.1007/s10658-015-0709-5.

Jiang, N. and H. Xu. 1998. Observation on Eriococcus lagerostroemiae Kuwana. Anhui Nongye Daxue Xuebao 2:142-144. (in Chinese).

Kozár, F., M.B. Kaydan, Z.K. Benedicty, and É. Szita. 2013. Acanthococcidae and related families of the Palaearctic region. Hungarian Acad. Sci., Budapest, Hungary.
Liao, C., C. Kao, W. Peng, Y. Chang, S. Lai, and Y. Ho. 2012. Analgesic and anti-inflammatory activities of methanol extract of Ficus pumila L. in mice. Evid. Based Complement Alternat. Med. article 340141, https:// doi.org/10.1155/2012/340141.

Ma, J. 2011. Occurrence and biological characteristics of Eriococcus lagerostroemiae Kuwana in Panxi district. South China Fruits 40:12-14. (in Chinese).

Martin, C. and S. Mott. 1997. American beautyberry (Callicarpa americana): Section 7.5.8, U.S. Army Corps of Engineers wildlife resources management manual. U.S. Army Waterways Exp. Sta., Vicksburg, MS.

Mazzi, D. and S. Dorn. 2012. Movement of insect pests in agricultural landscapes. Ann. Appl. Biol. 160:97-113, https:// doi.org/10.1111/j.1744-7348.2012.005 33.x.

McClure, M.S. 1990. Role of wind, birds, deer, and humans in the dispersal of hemlock woolly adelgid (Homoptera: Adelgidae). Environ. Entomol. 19:36-43, https://doi.org/10.1093/ee/19.1.36.

Merchant, M.E., M. Gu, J. Robbins, E. Vafaie, N. Barr, A.D. Tripodi, and A.L. Szalanski. 2014. Discovery and spread of Eriococcus lagerstroemiae Kuwana (Hemiptera: Eriococcidae), a new invasive pest of crape myrtle, Lagerstroemia spp. 16 Mar. 2019. <https://bugwoodcloud.org/resource/ pdf/ESAPosterDiscovAndSpread2014. pdf $>$.

Pei, C., S. Chen, W. Fang, S. Liou, L. Fu, G. Sheng, T. Zhuang, Y. Lan, R. Guo, and K. Yao. 1982. Verbenaceae. Science Press, Beijing, China.

Resasco, J., N.M. Haddad, J.L. Orrock, D. Shoemaker, L.A. Brudvig, E.I. Damschen, J.J. Tewksbury, and D.J. Levey. 2014. Landscape corridors can increase invasion by an exotic species and reduce diversity of native species. Ecology 95:2033-2039, https://doi.org/10.1890/14-0169.1.

Reynolds, D.R. 1999. Capnodium citri: The sooty mold fungi comprising the taxon concept. Mycopathologia 148:141-147, https://doi.org/10.1023/A:100717050 4903.

Schaffner, U. 2001. Host range testing of insects for biological weed control: How can it be better interpreted? Data on the host range of biocontrol candidates are particularly relevant in assessing potential detrimental effects to nontarget organisms. Bioscience 51:951-959, https://doi.org/ 10.1641/0006-3568(2001)051[0951:HR TOIF]2.0.CO;2.

Schoonhoven, L.M., J.J.A. van Loon, and M. Dicke. 2005. Insect-plant biology. 2nd ed. Oxford Univ. Press, New York, NY.
Tropicos.org. 1982. Missouri Botanical Garden. 12 May 2019. < https://www. tropicos.org/name/33700103>.

U.S. Department of Agriculture, Agricultural Research Service. 2012. USDA Plant Hardiness Zone Map. 10 Sept. 2021. $<$ https://planthardiness.ars.usda.gov>.

Vafaie, E., M. Merchant, X. Cai, J.D. Hopkins, J.A. Robbins, Y. Chen, and M. Gu. 2020. Seasonal population patterns of a new scale pest, Acanthococcus lagerstroemiae Kuwana (Hemiptera: Sternorrhynca: Eriococcidae), of crapemyrtles in Texas, Louisiana, and Arkansas. J. Environ. Hort. 38: 8-14, https://doi.org/10.24266/07382898-38.1.8.

Wang, Z., Y. Chen, M. Gu, E. Vafaie, M. Merchant, and R. Diaz. 2016. Crapemyrtle bark scale: A new threat for crapemyrtles, a popular landscape plant in the U.S. Insects 7:78, https://doi.org/10.3390/insects 7040078 .

Wang, Z., Y. Chen, and R. Diaz. 2019. Temperature-dependent development and host range of crapemyrtle bark scale, Acanthococcus lagerstroemiae (Kuwana) (Hemiptera: Eriococcidae). Fla. Entomol. 102:181-186, https://doi.org/10.1653/ 024.102.0129.

Ward, L.K. and D.F. Spalding. 1993. Phytophagous British insects and mites and their food-plant families: Total numbers and polyphagy. Biol. J. Linn. Soc. Lond. 49:257-276, https://doi.org/10.1111/ j.1095-8312.1993.tb00905.x.

Wong, M. 2007. Ficus plants for Hawai 'i landscapes. 20 Mar. 2019. <http://hdl. handle.net/10125/2955 $>$.

Wu, B., R. Xie, G. Knox, H. Qin, and M. Gu. 2021. Host suitability for crapemyrtle bark scale (Acanthococcus lagerstroemiae) differed significantly among crapemyrtle species. Insects 12:6, https://doi.org/ 10.3390/insects12010006.

Wu, L., C. Lei, L. Gao, H. Liao, J. Li, J. Li, and A. Hou. 2015. Isoprenylated flavonoids with PTP1B inhibition from Ficus tikoua. Nat. Prod. Commun. 10:21052107, https://doi.org/10.1177\%2F193 $4578 \mathrm{X} 1501001223$.

Xie, R., B. Wu, H. Dou, C. Liu, G. Knox, H. Qin, and M. Gu. 2020. Feeding preference of crapemyrtle bark scale (Acanthococcus lagerstroemiae) on different species. Insects 11:399, https:// doi.org/10.3390/insects1 1070399.

Zhang, Z. and Y. Shi. 1986. Studies on the morphology and biology of Eriococcus lagerstroemiae Kuwana. J. Anhui Agr. Univ. 17:61-66. (in Chinese). 